\title{
THE EFFECT OF TILLAGE SYSTEMS ON SOIL SEEDBANK
}

\section{Eleonora Wrzesińska, Stanisław Pużyński, Anna Komorowska}

\author{
Department of Agronomy, West Pomeranian University of Technology \\ Papieża Pawła VI 3, 71-459 Szczecin, Poland \\ e-mail: Eleonora.Wrzesińska@zut.edu.pl
}

Received: 07.05.2012

\begin{abstract}
The research was carried out in 2006-2008 in a static field experiment started in 1993 in the Research Field Station at Lipnik near Stargard Szczeciński, on Eutric Cambisol soil.

In soil samples taken from following layers: 0-10, 10-20, 20-30 cm of soil under ploughing, ploughless or direct drilling tillage systems, species composition and number of weed diaspores were evaluated. In the samples, in total there were diaspores of 17 weed species. Chenopodium album was the dominant weed species in all soil layers and tillage systems. The number of diaspores was significantly dependent on tillage system and soil layer. Irrespective of soil depth, the highest total number of diaspores $\left(12251 \mathrm{pcs} \times \mathrm{m}^{-2}\right)$ was in the treatment with the ploughing tillage system, while for the other treatments this number was significantly lower: by $14 \%$ for ploughless tillage and by $51 \%$ for the direct drilling treatment. Regardless of soil tillage system, the highest total number of diaspores (19936 pcs $\times \mathrm{m}^{-2}$ ) was in the top layer, while in the next layers this number was significantly lower (by 62 and $87 \%$, respectively). The largest number of weed diaspores was in the top layer of soil after long application of the ploughless tillage system.
\end{abstract}

Key words: soil tillage systems, soil layers, weed species, number of weed diaspores.

\section{INTRODUCTION}

Weeds growing on arable land originate almost exclusively from seeds being an integral part of the soil seedbank (B o chenek, 1998). Their number and arrangement in a soil profile depends on many elements, both natural and agricultural $(\mathrm{J}$ ę $\mathrm{drus} \mathrm{z}$ c zak et al. 2007; M a fecka and B lech arczyk, 2000; Pawłowski and Wesołowski, 1980; Radecki and Ciesielska, 2000; Zawiślak, 1980). Modifications of ploughing tillage, such as re- duced depth and frequency of ploughing, replacing tillage implements with some other ones, or even the elimination of soil tillage and replacing it with direct drilling, reduce soil cultivation costs, speed up seedbed preparation, protect soil environment, and increase productivity (Droese et al. 1986; Dzienia, 1995; W ł o d e k et al. 1999). Such tillage reductions may cause changes in weed infestation of crops and in soil seedbank. The results of the research carried out by Bochenek, 2000; Cardina et al. 1991; Conn, 2006; Feldman et al. 1992; Kordas and Zawieja, 2003; Krężel, 1991; Orzech et al. 2006; R a decki and Opic, 1995; Witkowski, 1998; Wojciechowski and Sowiński, 2005; Wrzesińs k a et al. 2003 and 2004; Z a w i e ja and K ord a s , 2003, have not given an unambiguous answer so far how tillage reductions affect the soil seed bank.

The aim of the study was to evaluate long-term application of three tillage systems (ploughing, ploughless and direct drilling) on species composition and number of weed diaspores in the plough layer of soil.

\section{MATERIALS AND METHODS}

The research was carried out in 2006-2008 in a static field experiment established in 1993 in the Research Field Station at Lipnik near Stargard Szczeciński, on Eutric Cambisol soil. The soil content was as follows: $11-13 \%$ clay, $1.3-1.5 \%$ humus, while its $\mathrm{pH}$ was 6.2 in $1 \mathrm{~mol} \mathrm{KCl}$.

The experiment was established as a split-plot design, with two factors: I - soil tillage system (A ploughing, B - ploughless, $\mathrm{C}$ - direst drilling); II - soil layer $(\mathrm{a}-0-10 \mathrm{~cm}, \mathrm{~b}-10-20 \mathrm{~cm}, \mathrm{c}-20-30 \mathrm{~cm})$. 
An estimation of seed diaspores was carried out after harvest of winter wheat - the last crop in the following crop rotation: sugar beet - winter wheat, faba bean - winter wheat. Soil cultivation treatments done prior to seeding of winter wheat are shown in Table 1. Soil samples for seed bank assessment were taken, using a $5 \mathrm{~cm}$ diameter cylinder, from given depths in four replications on every tillage treatment. To sepa- rate diaspores from solid soil, every sample was washed on a $0.11 \mathrm{~mm}$ mesh sieve and then dried. After that, undamaged and well-developed seeds and fruits of weed species were manually isolated and counted. For statistical analysis, the results were converted to a square meter basis. Analysis of variance was done using FR-ANALWAR 4.11 software, at a level of significance of 0.05 .

Table 1

Tillage systems

\begin{tabular}{lc}
\hline Tillage systems & Cultivation treatments \\
\hline A - ploughing & ploughing $-(25 \mathrm{~cm})$, harrowing - light harrow \\
B - ploughless & spraying with the herbicide Roundup 360 SL $\left(3 \mathrm{dm}^{3} \times \mathrm{ha}^{-1}\right)$, \\
C - direct drilling & spraying with the herbicide Roundup 360 SL $\left(3 \mathrm{dm}^{3} \times \mathrm{ha}^{-1}\right)$ \\
\hline
\end{tabular}

\section{RESULTS}

In total, diaspores of 18 species were identified in the soil of the experimental plots, all of them annual weeds (Table 2). Diaspores of 9 weed species were in every tillage treatment. A few weed species with a small number of diaspores were found in the soil after the particular soil tillage systems. Diaspores of Fumaria officinalis L., Myosotis arvensis (L.) Hill and Lycopsis arvensis L. were only found in the soil in the ploughed plots, whereas Bromus sterilis L. and Sinapis arvensis L. were only found after ploughless tillage and direct drilling. In the treatments with reduced soil tillage (ploughless tillage and direct drilling), seeds of Thlaspi arvense $\mathrm{L}$. were noted. Seeds of Agrostemma githago L. were only recorded in the soil after ploughless tillage, while diaspores of Veronica persica Poir. and Poa апnиа L. only after direct drilling application. Weed species diversity of soil seedbank after ploughing tillage and direct drilling was the same (13), while in the no-tillage treatment this number was lower by 3 species.

Regardless of tillage system, similar numbers of diaspores were found in the top $(0-10 \mathrm{~cm})$ and deepest $(20-30 \mathrm{~cm})$ layers of soil, whereas in the middle layer $(20-30 \mathrm{~cm})$ about 3 and 4 species fewer. In every layer, there were diaspores of the same 9 species. Diaspores of Agrostemma githago L. and Veronica persica Poir. were found only in the top layer, while in the middle layer - seeds of Fumaria officinalis L., Myosotis arvensis (L.) Hill, Lycopsis arvensis L., and Poa annua L. Seeds of Setaria viridis (L.) P. Beauv. were found both in the top and middle layers, while in the top and deepest layers - diaspores of Bromus sterilis L. and Sinapis arvensis L. In spite of some variation in species, Chenopodium album L. was the dominant species in terms of number of seeds, regardless of both tillage system and soil layer. The percentage of seeds of this species in the total number of seeds in the soil for the particular tillage systems was as follows: $56 \%$ ploughing tillage, $65 \%$ on ploughless tillage, and $76 \%$ direct drilling. In the top and deepest soil layers, the percentage of common lambsquarters seeds was similar (66 and 64\%, respectively), while in the middle layer $-57 \%$. The next species with a distinctly higher number of seeds and fruits were Viola arvensis and Fallopia convolvulus (L.) Á. Löve.

Both the factors, tillage system and soil layer, significantly differentiated the number of weed diaspores (Table 3). The highest number of diaspores (12 251 pcs. $\times \mathrm{m}^{-2}$ ) was after ploughing tillage, while in the treatments with ploughless tillage and direct drilling there were significantly less seeds - by 14 and $15 \%$, respectively.

Regardless of soil tillage, the highest number of weed seeds was found in the top layer - 19936 pcs. $\times \mathrm{m}^{-2}$ ), while in the deepest layer this number was significantly lower: in the middle layer by about $62 \%$, whereas in the deepest one by about $87 \%$, compared to the top layer.

The percentage of diaspores distributed in the soil layers was dependant on soil tillage systems (Fig. 1). The distribution of diaspores in the $0-30 \mathrm{~cm}$ soil layer was mostly the same in the plots where ploughing tillage or direct drilling was used. More than half of diaspores (56 and 63\%, respectively) in the soil under these systems were distributed in the top layer $(0-10 \mathrm{~cm})$. In the middle layer $(10-20 \mathrm{~cm})$, it was 33 and $30 \%$, while in the deepest one $(20-30 \mathrm{~cm})-11$ and $7 \%$, respectively. Ploughless tillage caused up to $80 \%$ of seeds and fruits of weeds to be deposited in the top 
layer, while the rest of diaspores were deposited in the deeper layers evenly. The results show that the impact of soil tillage systems is not unambiguous.

\section{DISCUSSION}

In the present study, weed species diversity in soil seedbank after ploughing tillage and direct drilling did not differ, whereas in the no-till plots the number of species was lower. This result did not confirm the results of Feldman et al. (1992) and Wrzes iń$\mathrm{s} \mathrm{k}$ a et al. (2004) who concluded that tillage that disturbs less the soil (cultivator or direct drilling) caused increased weed species diversity.

In the species composition of soil seedbank, diasporas of short-lived weeds prevail and only a few species are dominants. The results of our earlier research (W r zes ińs k a et al. 2003, 2004) as well as studies of other authors (B u ja k and Fran t, 2009; Idkowiak and Kordas, 2006; M a łecka and B lecharczyk, 2000; W ojciechowski and S owiński, 2005) also show that dicotyledonous species: Chenopodium album L, Fallopia convolvulus (L.) Á. Löve and Viola arvensis Murray, dominate in the seedbank.

The number of weed diaspores in the soil was dependant on soil tillage system. The highest number of diaspores was found after ploughing tillage was used, compared to ploughless tillage or direct drilling. This finding confirms earlier studies of $\mathrm{Wrzes}$ in $\mathrm{s} \mathrm{k}$ a et al. $(2003,2004)$ as well as Woj ci e chows ki and S ow ińs ki (2005). Similarly, B u jak and Fran t (2009) observed that the reduction of ploughing to three times in crop rotation leads to a decrease in seed bank supply. Other studies of B o c h e ne k (2000), C o n n (2006), K ordas and Z awieja (2003), K ręż e l (1991), R a d e cki and O pic (1995), S e k u tow s ki (2009), Zawie ja and Kordas (2003) show that the number of weed diaspores increases when soil tillage is reduced to direct drilling.

The distribution of diaspores in the deeper layers of soil observed in the present study is in accordance with numerous literature data $(\mathrm{Orzech}$ et al. 2006; R a de c ki and O pi c, 1995; Wr ze s ińs k a et al. 2003 and 2004). But the finding of $\mathrm{B} \mathrm{u} \mathrm{j} \mathrm{a} \mathrm{k} \mathrm{and}$ F r a n t (2009) shows an opposite relationship in changes in the distribution of weed diaspores; the lowest number of diaspores was in the top layer $(0-5 \mathrm{~cm})$, while in the next layers $(5-15 \mathrm{~cm}$ and $15-30 \mathrm{~cm})$ it was higher by 46 and $29.5 \%$, respectively.

The percentage distribution of weed diaspores in the soil layers was dependent on soil tillage system. Direct drilling affected it mostly the same as the ploughing tillage system. Earlier studies of Wr z e s i ń$\mathrm{s} \mathrm{k}$ a et al. $(2003,2004)$ show that such spatial distribution of weed seeds and fruits observed in the soil layers after ploughing was also found in the soil where ploughless tillage was used. In the opinion of $\mathrm{Car}$ din a et al. (1991), D or a d o et al. (1999), Feld man et al. (1992), Radecki and Opic (1995), and Un g e r et al. (1999), under no-till or zero tillage seeds are accumulated mostly in the top layer of soil. However, D or a d o et al. (1999) found in the case of ploughing tillage that diaspores were almost evenly distributed, but $\mathrm{Paw}$ a o s ki and P o m y kals ka (1980) observed that, regardless of ploughing depth, the spatial distribution of weed diaspores decreased in every deeper layer of soil.

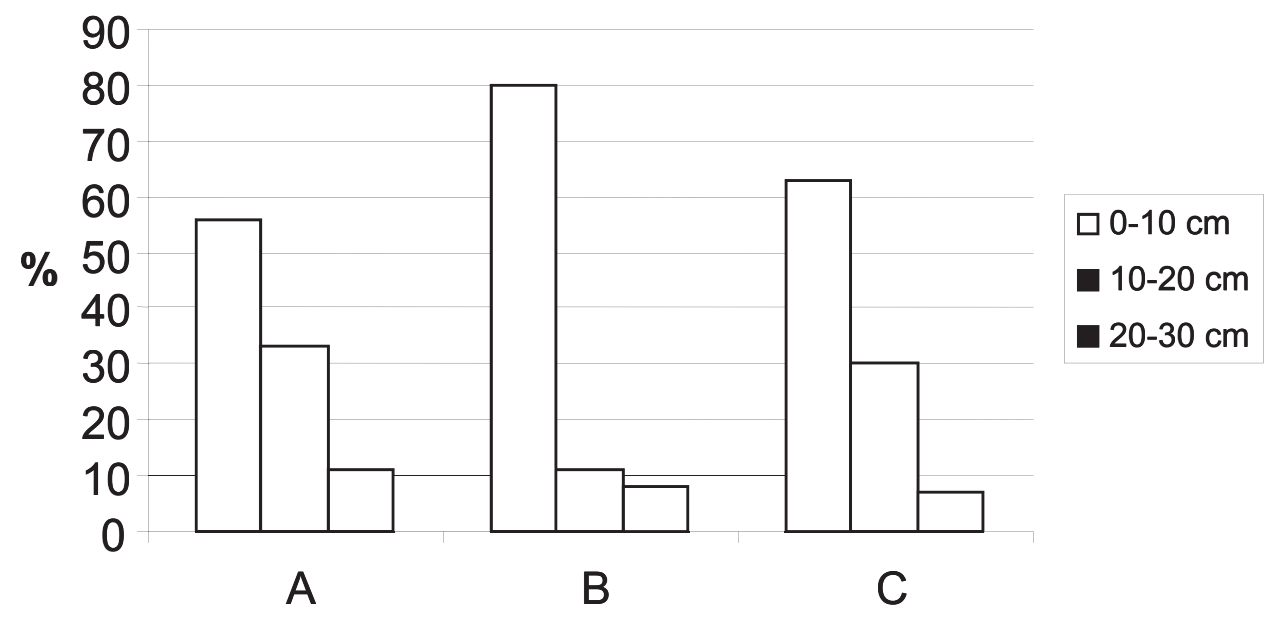

Soil tillage system

Fig. 1. Effect of tillage systems on weed seed distribution in the respective soil layers (\%). 
Table 2

Species diversity and number of weed diaspores in the soil in dependence on soil tillage system and depth of soil layers [pcs. $\times \mathrm{m}-2]$

\begin{tabular}{|c|c|c|c|c|c|c|}
\hline \multirow{2}{*}{ Weed species } & \multicolumn{3}{|c|}{ Tillage system } & \multicolumn{3}{|c|}{ Soil layer in $\mathrm{cm}$} \\
\hline & $A^{*}$ & $\mathrm{~B}$ & $\mathrm{C}$ & $0-10$ & $10-20$ & $21-30$ \\
\hline Chenopodium album $\mathrm{L}$. & 6819 & 6860 & 5531 & 13237 & 4281 & 1692 \\
\hline Viola arvensis Murray & 2752 & 1045 & 1156 & 3215 & 1486 & 252 \\
\hline Fallopia convolvulus (L.) Á. Löve & 1988 & 1772 & 107 & 2061 & 1297 & 509 \\
\hline Echinochloa crus-galli (L.) P.Beauv. & 342 & 560 & 141 & 710 & 197 & 136 \\
\hline Setaria viridis (L.) P. Beauv. & 204 & 188 & 127 & 456 & 63 & - \\
\hline Lamium amplexicaule L. & 71 & 37 & 59 & 74 & 89 & 4 \\
\hline Stellaria media (L.) Vill. & 37 & 68 & 48 & 93 & 41 & 19 \\
\hline Sinapis arvensis L. & 11 & - & 23 & 19 & - & 15 \\
\hline Fumaria officinalis L. & 7 & - & - & - & - & 7 \\
\hline Veronica hederifolia L. & 6 & 6 & 30 & 8 & 30 & 4 \\
\hline Lycopsis arvensis L. & 6 & - & - & - & - & 6 \\
\hline Bromus sterilis L. & 4 & - & 11 & 11 & - & 4 \\
\hline Myosotis arvensis (L.) Hill & 4 & - & - & - & - & 4 \\
\hline Thlaspi arvense L. & - & 22 & 41 & 37 & 19 & 7 \\
\hline Agrostemma githago L. & - & 4 & - & 4 & - & - \\
\hline Veronica persica Poir. & - & - & 11 & 11 & - & - \\
\hline Poa annua L. & - & - & 4 & - & - & 4 \\
\hline Total & 12251 & 10562 & 7289 & 19936 & 7503 & 2663 \\
\hline Number of species & 13 & 10 & 13 & 13 & 9 & 14 \\
\hline
\end{tabular}

A - ploughing; B - ploughless; C - direct drilling

Table 3

Number of weed diaspores in the soil in dependence on soil tillage systems and depth of soil layer [pcs. $\times \mathrm{m}-2]$

\begin{tabular}{lcccc}
\hline \multirow{2}{*}{ Tillage system } & \multicolumn{3}{c}{ Soil layer in cm } & \multirow{2}{*}{ Mean } \\
\cline { 2 - 4 } & $0-10$ & $11-20$ & $21-30$ & 12251 \\
\hline A - ploughing & 20533 & 12277 & 3944 & 10562 \\
B - ploughless & 25478 & 3619 & 2589 & 7289 \\
C - direct drilling & 13800 & 6613 & 1455 & \\
\hline \multicolumn{1}{c}{ Mean } & 19937 & 7503 & 2663 & \\
\hline LSD 0.05 for: & & & \\
$\quad$ tillage systems - 945 & & & \\
$\quad$ soil layer - 4 644 & & & \\
$\quad$ interaction: tillage system $\times$ soil layer - 2049 & & \\
\hline
\end{tabular}

\section{CONCLUSIONS}

1. The elimination of ploughing and the application of direct drilling do not cause changes in weed species dominance in soil seedbank.

2. Ploughing tillage favours the accumulation of weed seeds and fruits in soil, whereas ploughless tillage and direct drilling significantly decrease it.
3. The largest amount of weed diaspores accumulate in the top layer of soil $(0-10 \mathrm{~cm})$, whereas down the soil profile the number of diaspores significantly decreases.

4. In the top layer, the highest number of seeds and fruits of weeds were after long-term application of the ploughless tillage system. 


\section{REFERENCES}

B ochenek A. 1998. Ekofizjologiczne uwarunkowania dynamiki glebowego banku nasion chwastów / Ecophysiological determinants of the dynamics of weed seed soil bank. Post. Nauk Rol., Ser. A 6: 83-98 (in Polish).

B ochenek A. 2000. Wpływ czynników biotycznych i zabiegów uprawowych na glebowy bank nasion chwastów. / Impact of biotic factors and cultivation treatment on weed seed bank in the soil. Post. Nauk Rol. Ser. A 2: 19-29 (in Polish).

Bujak K., Frant M. 2009. Wpływ uproszczeń w uprawie roli i poziomu nawożenia mineralnego na zachwaszczenie potencjalne gleby. / Influence of reduced soil tillage and mineral fertilisation level on potential weed infestation. Acta Agroph. 13(2): 311-320 (in Polish).

Cardina M., Regnier E., Harrison K. 1991. Long-term tillage effects on seed banks in three Ohio soil. Weed Sci. 39: 186-194.

C o n n J.S. 2006. Weed seed bank affected by tillage intensity for barley in Alaska. Soil and Tillage Res. 90: 156-161.

Dorado J., Del Monte J.P., Lopez-Fando C. 1999. Weed seedbank response to crop rotation and tillage in semiarid agroecosystems. Weed Sci. 47: 67-73.

Droese H., Radecki L., Śmierzchalski L. 1986. Siew bezpośredni. / Direct drilling. Fragm. Agron. 2: 29-42. (in Polish)

D zie n i a S. 1995. Siew bezpośredni teorią alternatywną. [In:] Siew bezpośredni w teorii i praktyce. Materiały konferencji naukowej, Szczecin - Barzkowice 12 czerwca 1995. AR, Szczecin, 9-21 (in Polish).

Feldman S.R., Alzugary C., Tores P.S., Levis P. 1992. The effect of different tillage systems on the composition of the seedbank. Weed Res. 37: 71-76.

Idkowiak M., Kordas L. 2006. Wpływ sposobu uprawy roli i nawożenia azotowego na zawartość diaspor w glebie. / The effect of tillage system and nitrogen fertilization on weed seeds in the soil. Zesz. Nauk. UP we Wrocławiu. Rolnictwo LXXXIX, 546: 587-593 (in Polish).

Jędruszczak M., Budzyńska B., Gocół M. 2007. Zasobność glebowego banku nasion chwastów w zależności od sposobu regulacji zachwaszczenia. / Weed diaspore soil bank in dependence on methods of weed control. Ann. UMCS, Sect. E Agricultura 65: 217-225 (in Polish).

Kordas L., Zawieja J. 2003. Wpływ sposobu uprawy roli pod pszenicę jarą i jej przedplonu na zawartość diaspor chwastów w glebie. / The effect of soil tillage for spring wheat and preceding crop on weed seedbank content in soil. Zesz. Probl. Post. Nauk Rol. 490: 113120 (in Polish).

K rężel R. 1991. Wpływ siewu bezpośredniego na właściwości gleby i plonowanie roślin. / Effect of direct sowing on soil properties and yielding of crops. Rocz. Nauk Rol., Ser. A 109(2): 175-187 (in Polish).

Małecka I., Blecharczyk A. 2000. Zachwaszczenie potencjalne gleby pól Rolniczych Gospodarstw Do- świadczalnych Akademii Rolniczej w Poznaniu / Potential weed soil seedbank of the fields in the Experimental Farms of Agricultural University of Poznan (Poland) Ann. UMCS, Sect. E Agricultura 55: 133-141 (in Polish).

Orzech K., Buczyński G., Makowski P. 2006. Wpływ uproszczeń uprawy roli na zachwaszczenie potencjalne gleby średniej. / The influence of soil tillage simplifications on potential infestation of medium soil. Fragm. Agron. 2(90): 242-250 (in Polish).

Pawłowski F., Pomykalska A. 1980. Wpływ głębokości orki na liczebność i rozmieszczenie nasion chwastów w glebie. / Effect of ploughing depth on the number and distribution of weed seeds in soil. Zesz. Probl. Post. Nauk Rol. 227: 123-127 (in Polish).

Pawłowski F., Wes ołowski M. 1980. Zasób i skład gatunkowy nasion chwastów w różnych kompleksach gleb w południowo-wschodniej Polsce. / Number and species composition of weed seeds in various soil usefulness complexes in south-eastern Poland. Rocz. Nauk Rol. Ser. A 104(3): 87-100 (in Polish).

Radecki A., Ciesielska A. 2000. Zachwaszczenie łanu i gleby plantacji produkcyjnych rzepaku. / Weed infestation of a canopy and soil production of rape plantation. Ann. UMCS, Sect. E Agricultura, 55: 161-166 (in Polish).

Radecki A., O pic J. 1995. Wpływ zróżnicowanej uprawy na zachwaszczenie i zmiany zapasu nasion chwastów w glebie. [In:] Siew bezpośredni w teorii i praktyce. Materiały konferencji naukowej, Szczecin - Barzkowice 12 czerwca 1995, AR Szczecin, 119-134 (in Polish).

Sekutowski T. 2009. Wpływ systemów uprawy na liczbę i występowanie nasion chwastów w glebie. / Influence of tillage systems on the weed seed bank in soil. Zesz. Probl. Post. Nauk Rol. 543: 291-297 (in Polish).

Unger P.W., Miller S.D., Jones O.R. 1999. Weed seeds in long -term dryland tillage and cropping system plots. Wed Res. 39: 213-222. http://dx.doi.org/10. 1046/j.1365-3180.1999.00139.x

Witkowski F. 1998. Wpływ wieloletnich uproszczeń uprawy roli na liczbę i rozmieszczenie nasion w glebie / The impact of long-term simplified soil cultivation on the number and distribution of weed seeds in soil. Post. Nauk Rol. 1: 31-40 (in Polish).

Włodek S., Pabin J., Biskupski A., Kaus A. 1999. Skutki uproszczeń uprawy roli w zmianowaniu. / Effects of reduced tillage in crop rotation. Folia Univ. Agric. Stetin., Ser. Agricultura (74): 40-45 (in Polish).

Wrzesińska E., Dzienia S., Wereszczaka J. 2003. Wpływ systemów uprawy roli na ilość i rozmieszczenie nasion chwastów w glebie / Effect of different cultivation systems on the number and composition of weed seeds in soil. Acta Sci. Pol. Ser. Agricultura, 2(1): 169-175 (in Polish).

Wrzesińska E., Dzienia S., Wereszczaka J. 2004. Wpływ systemów uprawy roli na ilość i rozmieszczenie nasion chwastów w glebie. / Effect of different cultivation systems on the number and composition of 
weed seedbank. Fragm. Agronom. 2 (82): 52-60 (in Polish).

Wojciechowski W., Sowiński J. 2005. Changes in the number of weed seeds in soil under different tillage systems of winter wheat. J. Plant Prot. Res. 45(2): 83-92.

Zawieja J., Kordas L. 2003. Effect of simplified tillage and direct sowing on weed seedbank in soil. Acta Sci. Pol. Ser. Agricultura, 2(2): 163-170.

Z aw iślak K. 1980. Stopień specjalizacji zmianowań a aktualne i potencjalne zachwaszczenie stanowisk. / Specialized crop rotations in relation to actual and potential weed infestation of fields. Zesz. Nauk. ART Olszt., Ser Rolnictwo 29: 283-293 (in Polish).

\section{Wpływ systemów uprawy roli na zapas diaspor chwastów w glebie}

\section{Streszczenie}

Badania przeprowadzono w latach 2006-2008 w statycznym doświadczeniu polowym, założonym w 1993 roku w RZD Lipnik kolo Stargardu Szcze- cińskiego na glebie kompleksu żytniego dobrego. $\mathrm{W}$ próbach glebowych pobranych z trzech warstw gleby $(0-10,10-20,20-30 \mathrm{~cm})$ po różnych systemach uprawy roli (płużny, bezpłużny, siew bezpośredni) określono skład gatunkowy i liczebność diaspor chwastów. W badanych warstwach gleby oznaczono ogółem diaspory 17 gatunków chwastów. Na wszystkich obiektach uprawowych oraz w każdej warstwie gleby dominowały nasiona Chenopodium album. Liczebność diaspor w glebie istotnie zależała zarówno od zastosowanych systemów uprawy roli, jak i głębokości pobierania prób. Niezależnie od głębokości pobierania prób glebowych, najwięcej diaspor chwastów ogółem (12 251 szt. $\times \mathrm{m}^{-2}$ ) stwierdzono na obiektach $\mathrm{z}$ uprawą płużną, natomiast na pozostałych obiektach istotnie mniej: po uprawie bezpłużnej o $14 \%$, a po siewie bezpośrednim o $51 \%$. Niezależnie od zastosowanych systemów uprawy roli najwięcej diaspor (19 936 szt. × $\mathrm{m}^{-2}$ ) oznaczono $\mathrm{w}$ wierzchniej warstwie gleby a istotnie mniej w każdej następnej warstwie (odpowiednio o 62 i 87\%). W wierzchniej warstwie gleby najwięcej nasion i owoców chwastów stwierdzono po wieloletnim stosowaniu uprawy bezpłużnej. 